\title{
ERASMUS' ATTITUDE TOWARD ISLAM IN LIGHT OF NICHOLAS OF CUSA'S DE PACE FIDEI AND CRIBRATIO ALKORANI
}

\author{
Nathan Ron \\ The University of Haifa
}

\begin{abstract}
Reading Nicolas of Cusa's works on Islam reveals a sharp distinction between his De pace fidei (1453) with its tolerant attitude and his Cribratio Alkorani (1461) with its much less tolerant approach. Some eight years passed from the appearance of De pace fidei until the publication of Cribratio Alkorani. I argue that in the period between the appearances of these books, Cusanus changed his attitude to Islam, and the Turkish threat may have been the reason.

Certain historians have pointed to Desiderius Erasmus' objection to the waging of crusades and to the term semichristiani, which Erasmus occasionally used in reference to Muslims. According to these historians, the term semichristiani echoed Cusanus' optimistic view according to which the Turks were «half-Christian». However, I found that Cusanus never used this term in any of his writings, and that the term sits in Erasmus' writings side by side with manifest contempt and degradation expressed toward the Turks. Thus, Erasmus' rhetoric and hostile attitude toward the Turks and Islam was far from the moderation and toleration which Cusanus presented in his De pace fidei. In its attitude and spirit Erasmus' De bello Turcico should be compared to Cusanus' Cribratio Alkorani rather than to De pace fidei.
\end{abstract}

\section{Keywords}

Cusanus; Erasmus; Islam; Turks; 'Semischristiani'; crusade

\section{Introduction}

In his Complaint of Peace (Querela pacis, 1517) Erasmus described France as the purest Christian land: «The law flourishes as nowhere else, nowhere has religion so retained its purity without being corrupted by commerce carried 
on by the Jews, as in Italy, or infected by the proximity of the Turks or Marranos, as in Hungary and Spain». ${ }^{1}$ Erasmus expressed the same idea in a letter of March 10th, 1517: "Only France is not infected with heretics or Bohemian schismatics nor Jews or half-Jew Marranos, and there are no Turks to be found in its vicinity». ${ }^{2}$

Erasmus presented a correlation between the prosperity of a Christian country and the exclusion of non-Christians from its territories. Undoubtedly, Erasmus' rhetoric of purification and purgation had little in common with the idea of "one religion in a variety of rituals» (una religio in rituum varietate), which illuminates De pace fidei. ${ }^{3}$ It is not that Erasmus did not wish for the conversion of Jews and Muslims to Christianity, but that his rhetoric in this regard was often harsh and racial by its implications. ${ }^{4}$ Thus, while Erasmus' rhetoric of an idyllic vision of Christendom is often exclusivist, Cusanus presents in his De pace Fidei a model which, both in content and in rhetoric, may be defined as positive and as "inclusion instead of exclusion». ${ }^{5}$ Conversely the shift in Cusanus' attitude toward Islam implied in his later

${ }^{1}$ CWE 27, p. 306; ASD IV-2. p. 80: «florent leges nusquam illibatior religio, nec commercio Judaeorum corrupta, velut apud Italos, nec Turcarum vel Maranorum vicina infecta».

${ }^{2}$ CWE 4, p. 279, Ep 549: 11-13: «Sola Gallia nec haereticis est infecta nec Bohemis schismaticis nec Iudeis nec semiiudeis Maranis, nec Turcarum confinio afflata».

${ }^{3}$ The next chapter of the article deals with that.

${ }^{4}$ Erasmus' future vision (Ep 1800, 236-247, a letter sent to João III king of Portugal): «[...] the world will not be shaken by so many wars, or so many differences of ideas, and we will be free both of Judaism and paganism; and Christ will reign over us and under his standard we will prosper happily and peacefully. Finally, the limits of Christian rule will extend over distances». For his harsh and often racial expressions, see Oberman, H.A., The Roots of Anti-Semitism in the Age of Renaissance and Reformation, trans. Porter, J.L., Philadelphia, Fortress Press, 1984, pp. 38-39; idem, The Impact of the Reformation Grand Rapids, MI, Michigan, Eerdmans, 1994, p. 103; Pabell, H., «Erasmus of Rotterdam and Judaism: A Reexamination in Light of New Evidence», Archiv für Reformationsgeschichte, 87 (1996), pp. 9-37; Ron, N., «Erasmus Ethnological Hierarchy of Peoples and Races», History of European Ideas, 44 (2018), pp. 1063-1075.

${ }^{5}$ For «positive», see: Volf, M., Allah. A Christian Response, New York, HarperOne, 2011, pp. 40-59; Valkenberg, P., «Una religio in rituum varietate: Religious Pluralism, the Qur'an, and Nicholas of Cusa», in I.C. Levy, R. George-Tvrtković and D.F. Duclow (eds.) Nicholas of Cusa and Islam: Polemic and Dialogue in the Late Middle Age, Leiden, Brill, 2014, p. 30. For «inclusion instead of exclusion», see Euler, W.A., «A Critical Survey of Cusanus' Writings on Islam», in op. cit., pp. 20-29 at pp. 22-23. 
Scrutiny of the Qur'an (Cribratio Alkorani, 1461), could be defined as «exclusion instead of inclusion».6

The Cribratio presents a completely different, negative approach by Cusanus, which does not allow us to ascribe to him an attempt at a dialogue with Islam, whether theological, religious, or political. An important aspect of such a dialogue is studying the basic texts of the "Other». But studying the language or texts of the "Other» and understanding the "Other», cannot necessarily be considered as an attempt at creating a dialogue of peace. It might instead be intended as a tool for getting to know the enemy in order to overcome him. Luther's interest and his various involvements in the study of Islam clearly demonstrate this. ${ }^{7}$ Cusanus did study the fundamentals of Islam, and with some profundity, on several occasions during his lifetime (but not the Arab language), and his De pace fidei can be considered an attempt at a religious dialogue. By contrast in the Cribratio, Cusanus used his knowledge of the Qur'an not to draw rival religions closer together but to establish the superiority of one (Christianity) over the other (Islam).

Cusanus' attempt at creating a dialogue between conflicting religions, and his study of the Qur'an in order to compose an «inclusive instead of exclusive» work deserves praise, unlike his efforts to establish Christian superiority over Islam in Scrutiny of the Qur'an. ${ }^{8}$ Ironically, Erasmus, the prince of humanists, did not trouble himself with studying Islam or the Qur' an, although he wrote a treatise dedicated to the Turkish issue, namely A Most Useful Discussion Concerning Proposals for War Against the Turks (Utilissima consultatio de bello Turcis

${ }^{6}$ Euler (op. cit.) coined «Inclusion instead of exclusion» regarding De pace fidei. He explains how this attitude changed and reversed as Cusanus proceeded with his writings.

${ }^{7}$ Luther was interested in learning about Islam and complained of the insufficient knowledge of Christians on the enemy of Christianity. The case of Erasmus reaffirms that. For Erasmus the Turks or Islam were not a subject for study, not even as «know your enemy». See CWE 64, p. 258, n. 236; Francisco, A.S., Martin Luther and Islam: A Study in Sixteenth-Century Polemics and Apologetics, Leiden, Brill, 2001, p. 1; Miller, G.J., «Luther on the Turks and Islam», in T.L. Wengert (ed.) Harvesting Martin Luther's Reflections on Theology, Ethics, and the Church, Grand Rapids, MI, Eerdmans, 2004, pp. 185-206 (first published in Lutheran Quarterly, (2000), pp. 79-97); Schwoebel, R., The Shadow of the Crescent. The Renaissance Image of the Turk 1453-1517, New York, St. Martin's Press, 1967, pp. 208-209.

${ }^{8}$ On his study of the Qur'an: Biechler, J.E., «Three Manuscripts on Islam from the Library of Nicholas of Cusa», Manuscripta, 27 (1983), pp. 91-100; Euler, W.A., «An Italian Painting from the Late Fifteenth Century and the Cribratio Alkorani of Nicholas of Cusa», in P.J. Casarella (ed.) Cusanus. The Legacy of Learned Ignorance, Washington, DC, Catholic University of America Press, 2006, p. 142; M. Watanabe, "An Appreciation», in C.M. Bellitto, T.M. Izbicki and G. Christianson (eds.), Introducing Nicholas of Cusa: A Guide to a Renaissance Man, Mahwa, NJ, Paulist Press, 2004, p. 8. 
inferendo, 1530), also known as De bello Turcico. ${ }^{9}$ It was published in March 1530, shortly after the Turks raised their siege on Vienna, and written very much as a response to Martin Luther's stance on the issue of war against the Turks. Luther principally opposed fighting the Turks and Erasmus meant to dispute that. Meanwhile Luther changed his mind in favor of fighting the Turks. Erasmus, who learned about it with some delay, wrote his treatise irrespective of Luther's change of mind. ${ }^{10}$

Unlike Christian polemics against Islam, Erasmus' moral goal in this treatise was to sound an alarm call to Christians to change their ways. ${ }^{11}$ Finally, the treatise has a fundamental element that does not match classic antiIslamic polemics: Erasmus' opposition to the institution of crusade, namely a war initiated and sponsored by the Church, whether against the Turks or others. "We have heard so often of crusading expeditions, of recovering the Holy Land; we have seen so often the red cross emblazoned with the triple crown, and the red chest beside it [...] and the only thing to triumph has been money [...] how can we, who have been misled thirty times over, believe any more promises $[. ..] »^{12}$

Although not a Christian polemic against Islam, the treatise make use of harsh and blatant anti-Turkish and anti-Muslim rhetoric. It contains Erasmus' only written reference relating to the essence of Islam:

But what shall I say about their system of government? Where is the rule of law among them? Whatever pleases the tyrant, which is the law. Where is the

${ }^{9}$ For the Latin text: ASD V-3, pp. 32-82 (ed. A.G. Weiler). For the English translation, see Heath, M.J., (translator) A Most Useful Discussion Concerning Proposals for War against the Turks Including an Exposition of Psalm 28 (Utilissima consultatio de bello Turcis inferendo, et obiter enarratus psalmus 28), in CWE vol. 64 (Expositions of the Psalms).

${ }^{10}$ Rummel, E., (ed.), The Erasmus Reader, Toronto, University of Toronto Press, 1996, 315; Heath, M.J., Introduction to «A Most Useful Discussion Concerning Proposals for War against the Turks Including an Exposition of Psalm 28» (Ultissima consultatio de Bello Turcis inferendo, et obiter enarratus psalmus 28), in CWE 64 (Expositions of the Psalms), 205.

${ }^{11}$ See Weiler, A.G., «The Turkish Argument and Christian Piety in Desiderius Erasmus' 'Consultatio de Bello Turcis inferendo' (1530)», in W.J. Sperna and W.T.M. Frijhoff (eds.), Erasmus of Rotterdam the Man and the Scholar, Leiden, Brill, 1988, pp. 30-39.

${ }^{12}$ CWE 64, 246; ASD V-3, 64. For Erasmus' anti-Crusade attitude as allegedly indicating moderation, see Bisaha, N., Creating East and West: Renaissance Humanists, and the West, Philadelphia, University of Pennsylvania Press, 1967, 175; Schwoebel, R., The Shadow of the Crescent: The Renaissance Image of the Turk 1453-1517. New York, St. Martin's Press, 1967, 225. As argued further on, despite his objection to the institution of Crusade, Erasmus' attitude toward Islam was not necessarily moderate. On this issue, see Ron, N., «The Christian Peace of Erasmus», The European Legacy, 19 (2014), pp. 27-42. 
power of a parliament? What room is there for philosophy? For schools of theology? For holy sermons? For true religion? Their sect is a mixture of Judaism, Christianity, paganism, and the Arian Heresy. They recognize Christ just as one of their prophets [...] Do they prefer the sordid and wicked man that Muhammad over Jesus, for which each bow in heaven, on earth and in hell? ${ }^{13}$

Muhammad is mentioned once more in this treatise: «[...] they rule due to God's anger, they fight us without God, they have Muhammad as their savior, we have Christ». ${ }^{14}$ The word "they» refers here to the Turks. As a rule, Erasmus did not deal with Islam, focusing rather on the Turks. The aforesaid paragraph is thus a rare exception as far as Erasmus' writings are concerned, because it does reveal his attitudes to Islam.

Even though Erasmus believed that the conversion of the Turks should be secured through non-brutal means, he nonetheless thought that it would require using the power of the state machinery; non-brutal, perhaps, but nevertheless an enforcement of Christianity.

The best solution of all would be to conquer the Turks' empire in the way in which the apostles conquered all the peoples of the earth for their master, Christ; but the second alternative must be to have as the chief object of an armed campaign that the Turks will be glad to have been defeated. This task will be made easier if, firstly, they see that Christianity is not mere words, and can observe that our deeds are worthy of the Gospel; secondly, if honest preachers are sent in to reap the harvest, men will further Christ's interests, not their own. Thirdly, if any infidel cannot so quickly be persuaded, he should be allowed to live under his own laws, until gradually he comes to agree with us. Long ago, Christian emperors used this method to abolish paganism in degrees. At first, they allowed the pagans to live on equal terms with our Christians, in such a way that neither interfered with the others. Then they deprived the idolaters' temples of their privileges, and finally, after forbidding the sacrifice of victims in public, they abolished the worship of idols completely. In this way

${ }^{13}$ CWE 64, 258-259; ASD V-3, 76: «Quid autem dicam de politia? Quae legume aequitas apud illos? Quidquid tyranno placuit, lex est. Quae Senatus auctoritas? Quae Philosophia locum illic habet? Quae Theologorum scholae? Quae sacrae conciones? Quae Religionis sinceritas? Sectam habent ex Judaismo, Christianismo, Paganismo et Arianorum haeresis commixtam. Agnoscunt Christum ut unum quempiam ex Prophetis [...] Quid, quod pestilentem ac scelerosum hominem Machumetem Christo, in cujus nomine flectitur omne genu coelestium, terrestrium, et infernorum, praeferunt?» See also Ron, «The Christian Peace of Erasmus», op. cit., pp. 32, 34-38.

${ }^{14}$ CWE 64, 231; ASD V-3, 50: «Regnant irato Deo, pugnant adversum nos sine Deo, illi Mahometem habent propugnatorem, nos Christum». 
our religion gradually grew stronger, paganism was stamped out, and the signs of Christ's triumph filled the world. ${ }^{15}$

This, Erasmus thought, was how peace with the Turks should be achieved, by converting the Turks to Christianity. Notedly, not by using brutal force against them, but, if necessary, by taking measures such as the Roman emperors, in particular Theodosius, took against pagans.

\section{Two Books, Two Views}

Cusanus' De pace fidei appearance in 1453, shortly after the fall of Constantinople to the Ottomans, may be considered as one of Cusanus' responses to that catastrophe. ${ }^{16}$

${ }^{15}$ CWE 64, 265; ASD V-3, 81: «Illud in primis erat optabile, si liceat Turcarum ditiones ita subigere, quamadmodum Apostoli cunctas mundi nationes subegerunt Imperatori Christo: proximum esto votum, sub armis hoc pottissimum agere, ut se victos esse gaudeant. Ad id praecipue conducet, si viderint Christianismum non esse verba, sed in nobis conspexerint mores Evangelio dignos. Tum, si mittantur in messem integri Praecones, qui non quaerant quae sua sunt, sed quae Jesu Christi. Postremo, si qui nondum possunt allici, sinantur aliquamdiu suis vivere legibus, donec paulatim nobiscum coalescent. Sic olim Imperatores Christiani paulatim aboleverunt Paganismum. Initio patiebantur illos aequo cum nostratibus Jure vivere, sic ut neutri alteris facesserent negotium. Deinde, templis idololatrarum ademerunt sua privilegia. Postremo, victimas ab illis immolari palam, vetuerunt, mox omnem simulacrorum cultum submoverunt. Ita sensim invalescente nostra Religione, Paganismus extinctus est, et Christi trophea mundum universum occuparunt». Erasmus finds no fault in Theodosius' systematic persecution of pagans and heretics, particularly Arians. According to Erasmus, the Arians were not just heretics, blatantly sacrilegious, but also rebels who threatened the political order; therefore, their persecution and execution was justified. Theodosius' Imperial edicts, issued from February 380 onward, were essentially, as can also be concluded from their phrasing, nothing less than the expression of imposed Christianization on various populations. This was justified, and even glorified, by Erasmus. For the texts of the Theodosian edicts: Peters, E., (ed.), Heresy and Authority in Medieval Europe. Documents in Translation, Philadelphia, University of Pennsylvania Press, 1980, pp. 42-47. See also Williams, G.F. and S., Theodosius: The Empire at Bay, London, Routledge, 1998, pp. 53-56; Wilken, R.L., John Chrysostom and the Jews: Rhetoric and Reality in the Late 4th Century, Berkeley and Los Angeles, University of California Press, 1983, pp. 13-32.

${ }^{16}$ Watanabe, M., «Cusanus, Islam, and Religious Tolerance», in I.C. Levy, R. GeorgeTvrtković and D.F. Duclow (eds.), Nicholas of Cusa and Islam: Polemic and Dialogue in the Late Middle Age, Leiden, Brill, 2014, p. 9; Euler, W.A., «A Critical Survey of Cusanus' Writings on Islam», in Levy, George-Tvrtković and Duclow (eds.) Nicholas of Cusa and Islam, op. cit., p. 21. 
Though Cusanus axiomatically presupposes the greater truths and weight of Christianity over other faiths, De pace fidei signified a belief in the close relationships of all faiths, predominantly Christianity and Islam. Furthermore, in this work Cusanus considered the formation of a universal religion, one that all believers could accept.

[...] and all [men] will know that there is only one religion in a variety of rites. But perchance this difference of rites cannot be eliminated; or perhaps it is not expedient [that it be eliminated], in order that the diversity may make for an increase of devotion, since each region will devote more careful attention to making its ceremonies more 'favorable,' as it were, to You, the King. If so, then at least let there be one religion - just as You are one - and one true worship of You as Sovereign. ${ }^{17}$

The different speakers in the De pace fidei are a Greek, an Italian, an Arab, an Indian, a Chaldean, a Jew, a Scythian, a Frenchman, a Persian, a Syrian, a Spaniard, a Turk, a German, a Tartar, an Armenian, a Bohemian, and Englishman. Together they conduct a non-polemical philosophical and theological discussion (not a debate), in which spirits of positive inclusiveness, tolerance and optimism are predominant. Thus, when the issue of the acceptance of the holy trinity by non-Christians is discussed, even the Jew, who represents the most stubborn of all nations, responds with the following positive words: «The Super-blessed Trinity, which cannot be denied, has been explained very well...And although Jews shun the [doctrine of] the Trinity because they have considered the Trinity to be a plurality, nonetheless once it is understood that [the Trinity] is most simple fecundity, [the Jews] will very gladly give assent». ${ }^{18}$ At most, even if they will not accept the new religion, «the Jews will not impede harmony, for [the Jews] are few in number and will not be able to trouble the whole world by force of arms». ${ }^{19}$

${ }^{17}$ Hopkins, J. (trans.), Complete Philosophical and Theological Treatises of Nicholas of Cusa, 2 vols., Minneapolis, Banning, 2001, p. 635; De pace fidei, I, 7, 10-15: «[...] et cognoscent omnes quomodo non est nisi religio una in rituum varietate. Quod si forte haec differentia rituum tolli non poterit aut non expedit, ut diversitas sit devotionis adauctio quando quaelibet regio suis cerimoniis quasi tibi regi religio et unus latriae cultus».

${ }^{18}$ Hopkins, p. 646; De pace fidei, IX, 26, 4-10: «Optime explanata est super-benedicta trinitas, quae negari nequit [...] Et quamvis Iudaei fugiant trinitatem propter hocquia eam putarunt pluralitatem, tamen intellecto quod sit fecunditas simplicissima perilbenter acquiescent».

${ }^{19}$ Hopkins, p. 654; De pace fidei, XII, 39, 13-15: «Haec tamen Iudaeorum resistentia non impediet concordiam. Pauci enim sunt et turbare universum mundum armis non poterunt». 
Finally, in his concluding lines, Cusanus linked his universal religion to perpetual peace, since such a religion is to end religious conflicts and wars and to establish concord and consensus instead.

Moreover, [He commanded] that thereafter [these wise men], having full power [to speak] for all [in their respective nations], assemble in Jerusalem, as being a common center, and in the names of all [their countrymen] accept a single faith and establish a perpetual peace with respect thereto, so that the Creator of all, who is blessed forever, may be praised in peace. ${ }^{20}$

In Joshua Hollman's Religious Concordance, he emphasizes the centrality of peace in Cusanus's De pace fidei: «De pace fidei expounds Cusanus's Christocentric and Platonic-panoramic prayer for religious peace». ${ }^{21}$

Cusanus believed that the different rituals and practices of the various religions had a common core of divine doctrine, which was shared by believers of all religions. De pace fidei set a standard of religious inclusiveness which was innovative and tolerant for its time and promoted interfaith dialogue. But when ascribing any degree of religious toleration to Cusanus, we should remember to conceptualize it in terms of his own time and reality, which was extremely intolerant fifteenth-century Europe. The modern idea of religious toleration can be equated with ideas of religious freedom, or religious pluralism, which started to evolve in sixteenth century Europe following the execution of Michael Servetus (1509 or 1511-1553). ${ }^{22}$ Furthermore, as Aikin and Aleksander point out: «Nicholas is a theological exclusivist who attempts to accommodate a degree of religious pluralism on behalf of the practical aim of promoting interreligious toleration». ${ }^{23}$

${ }^{20}$ Hopkins, p. 670; De pace fidei, XIX, 62, 20 - 63, 5: «Et mandatum est per Regem regum ut sapientes redeant et ad unitatem veri cultus nationes inducant, et quod administratorii spiritus illos ducant et eis assistant et deinde cum plena omnium potestate in Iherusalem quasi ad centrum commune confluant et omnium nominibus unam fidem acceptent et super ipsa perpetuam pacem firment, ut in pace creator omnium laudetur in saecula benedictus. Amen».

${ }^{21}$ Hollmann, Religious Concordance, op. cit., p. 177 (for the citation).

${ }^{22}$ On the evolvement of religious toleration in 16th century Europe. See Guggisberg, H.R., Sebastian Castellio, 1515-1563. Humanist and Defender of Religious Toleration in a Confessional Age, trans. B. Gordon, Aldershot, Ashgate, 2003; Guggisburg, H.R., «The Defence of Religious Toleration and Religious Liberty in Early Modern Europe: Argument, Pressures and Some Consequences», History of European Ideas, 4 (1983): pp. 36, 38; Zagorin, P., How the Idea of Religious Toleration Came to the World, Princeton, Princeton University Press, 2003, p. 6.

${ }^{23}$ Aikin, S.F., and Aleksander, J., «Nicholas of Cusa's De pace fidei and the MetaExclusivism of Religious Pluralism», International Journal for Philosophy of Religion, 74 (2013), p. 219. 
De pace fidei was probably the first Christian work which openly coped with the issue of a universal religion without suggesting conversion to Christianity as a solution. ${ }^{24}$ Even Norman Daniel, who criticizes Cusanus for not being an expert on Islam, recognizes in him the outstanding figure of his time for his conception of humankind. ${ }^{25}$

Some Cusanus scholars, such as James E. Biechler and H. Lawrence Bond, locate De pace fidei within "the literature of utopia». ${ }^{26}$ And Cusanus' vision is indeed utopian and irenic by its implications, aimed at the improvement of human relations by presenting a vision of a universal religion achieved by peaceful agreement between Muslims and Christians and based on the acceptance of ritual differences within the framework of that religion. Once implemented, the outcome of this inspiring ideal would be, as Cusanus proposed, the existence of an idyllic perpetual peace. This vision is to be linked with Cusanus' support of Conciliarism, the movement for a more open and self-critical Church. Cusanus was active at the Council of Basel (1432-1437), and he considered the Council a tool for holding deliberations attended not just by Christians, but by Christians and Muslims. If such a council was effective in dealing with major Christian issues, then why not try such a model for improving Christian-Muslim relations? ${ }^{27}$ In modern terms one may think

${ }^{24}$ Hopkins, pp. 4-7; Biechler, J.E., «Christian Humanism Confronts Islam: Sifting the Qur'an with Nicholas of Cusa», Journal of Ecumenical Studies, 13 (1976), p. 8; Biechler, «A New Face Toward Islam: Nicholas of Cusa and John of Segovia»; Izbicki, T.M., «The Possibility of Dialogue with Islam in the Fifteenth Century», in G. Christianson and T.M. Izbicki (eds.) Nicholas of Cusa: In Search of God and Wisdom. Essays in Honor of Morimichi Watanabe by the American Cusanus Society, Leiden, Brill, 1999, pp. 187, 176 (respectively); Biechler, J.E., «Interreligious Dialogue» (ch. 9) in C.M. Bellitto, T.M. Izbicki and G. Christianson (eds.) Introducing Nicholas of Cusa. A Guide to a Renaissance Man, Mahwah, NJ, Paulist Press, 2004, p. 274.

${ }^{25}$ Daniel, N., «The Image of Islam in the Medieval and Early Modern Period», in A. Nanji (ed.) Mapping Islamic Studies. Genealogy, Continuity and Change, Berlin, De Gruyter, 1997, pp. 139-140; Francisco, Martin Luther and Islam, op. cit., pp. 17-18.

${ }^{26}$ Biechler, J.E., and Bond, H.L., Nicholas of Cusa on Interreligious Harmony. Text, Concordance and Translation of De Pace Fidei, Lewiston, NY, Edwin Mellen Press, 1990, pp. xxvi-xvii; Gandillac, M. de, «Una religio in rituum varietate», in R. Haubst (ed.) Nikolaus von Kues als Promotor der Oekumene, Mitteilungen und Foerschungbeitraege der CusanusGesellschaft, 9 (1971), p. 204; Valkenberg, «Una religio in rituum varietate», op. cit., p. 32.

${ }^{27}$ Southern, R.W., Western Views of Islam in the Middle Ages, Cambridge, MA: Harvard University Press, 1962, p. 86; Bisaha, N., Creating East and West, Renaissance Humanists and the Ottoman Turks, Philadelphia, University of Pennsylvania Press, 2004, p. 145. 
of the League of Nations or the United Nations as an equivalent realization of such a council. ${ }^{28}$

Cusanus' Scrutiny of the Qur' an is a very different kind of text. It is basically an attempt to confirm Gospel truths through a critical reading of the Qur' an and a dismantling of its teachings by means of logical arguments. In the first book of the Cribratio, the oneness of God is emphasized, and criticism of, Islam does not take up much of the text. Nevertheless, already in Chapter I (book I), Cusanus denounces the Koran: «For in the book there are contained teachings which - because of their turpitude, injustice, and flagrant lies and contradictions - cannot without blasphemy be ascribed to God». ${ }^{29}$ By implication Satan must have delivered the Koran to Muhammad, and therefore all those prima facie praiseworthy references to Christ and the Gospels in the Koran, are essentially deceitful. Cusanus says in the same Chapter:

And although [the Koran] is seen to contain many testimonies of praise for the Testament, for the Gospel, and for the Prophets Abraham, Moses, and especially Jesus Christ, the son of the Virgin Mary, nevertheless since it contradicts all these [writings and writers] with respect to [its account of] the true and salvific end (as will be evident subsequently), these praises are [best] believed to have been placed [in the Koran] in order to deceive. ${ }^{30}$

In the latter part of the work, particularly in Chapter 19 of Book II, entitled "An Invective against the Qur' an», a change takes place and harsh criticisms of the Qur'an become frequent. ${ }^{31}$ Among the chapter-titles of part III, in the prologue, the following stand out:

II. Muhammad did not know what ought to be done and what ought to be believed; and he left behind nothing firm. III. Why those who believe the Koran are called "saved ones»; and that the sword is teacher. VIII. The goal of Muhammad's work was his own exaltation. IX. At times Muhammad writes that Christ is God and man; at times, that He is only a man. Similarly, at times [he writes] that God is one; at times, that He is more than one. X. Muhammad

${ }^{28}$ Valkenberg, «Una religio in rituum varietate», op. cit., p. 32.

${ }^{29}$ Hopkins, p. 975; Cribratio Alkorani, I, p. 23, 18-20: «[...] cum illa in libro contineantur, quae ob suam turpitudinem iniustitiam et notorietatem mendacii et contradictionis deo sine blasphemia adscribi nequeant».

${ }^{30}$ Hopkins, p. 976; Cribratio Alkorani, I, p. 24, 14-18: «Et licet multa videatur testimonia continere delaude testamenti et evangelii et prophetarum Abrahae, Moysi et maxime Iesu Christi filii Mariae virginis tamen cum illis omnibus quo ad verum et salutarem finem contradicat, ut infra patebit, potius addecipiendum haec laudes positae credentur».

${ }^{31}$ Hopkins, pp. 1045-1048; Cribratio Alkorani, II, 124, 2 - 158, 15 (Invectio Contra Alkoranum); Watanabe, «Cusanus, Islam, and Religious Tolerance», op. cit., p. 13. 
continually changes [his views], as [is instanced] in his examples. XIV. The covenant between God and Abraham excludes the Ismaelites, and it concludes in Christ, the Mediator. XV. Only the Christian, who adores Trinity-inoneness, can be a descendant of Abraham. XVI. Arabs are altogether ignorant of the law of Abraham, and they are persecutors of it. ${ }^{32}$

Unsurprisingly, the conclusion of Cusanus' scrutiny is that the Qur' an, as opposed to the scriptures, is neither intelligible nor divine. ${ }^{33}$

The Cribratio reflects Cusanus' hardening line toward Islam at that time. From a theological point of view, one can say, just as Walter A. Euler summarized, that in De pace fidei Cusanus ignored the anti-Christian side of Islam and presented it instead as a misunderstanding. However, in his letter to John of Segovia, (December 29, 1454) Cusanus implied that he was aware of the ambivalence of the Qur'an toward Christianity, ${ }^{34}$ which in Cribratio he discusses extensively, and this letter may offer up evidence of an intermediate step in his thinking. ${ }^{35}$

${ }^{32}$ Hopkins, pp. 973-974; Cribratio Alkorani, prologus, pp. 19-20, 4-30: «II. Quod Mahumetus ignoravit, quid agendum et sentiendum, et nihil firmi reliquit. III. Cur dicuntur salvati credentes Alkoranum; et quod gladius est magister. VIII. Quod finis operis Mahumeti fuit sui exaltatio. IX. Quod Mahumetus nunc scribat Christum deum et hominem, nunc hominem tantum, sic nunc singularem deum, nunc pluralem. X. Quod Mahumetus continue variat, ut in exemplis. XIV. Quod pactum dei et Abrahae excludit Ismaelitas et in Christo mediatore concluditur. XV. Quod non nisi Christianus trinitatem in unitate adorans Abrahae filius esse possit. XVI. Quod Arabes legem Abrahae penitus ignorent et eius sint persecutores».

${ }^{33}$ Cribratio Alkorani, XIX, p. 71, 13-14: «[...] ut sic de Alkorano recedant ad evangelium Christi totum intellectuale et divinum». Hopkins, p. 1005: «[the less well educated among the Arabs] may pass from the Qur'an to the whole Gospel-of-Christ which is intelligible and divine».

${ }^{34}$ At the council of Basel, Cusanus was engaged in discussion with John of Segovia, who in addition to being a Spanish delegate to the Council was also a theologian at the University of Salamanca. His contacts with the Moors, brought him to examine the claims of the Qur'an, and his association with Cusanus served to stimulate the latter's own interest in Islam. See Hopkins, «Introduction», p. 14; Southern, Western Views of Islam in the Middle Ages, op. cit., p. 92. On the aforesaid letter of Cusanus to John: Biechler, J.E., "Correspondence with John of Segovia»" in Ch.M. Bellitto, T.M. Izbicki and G. Christianson (eds.) Introducing Nicholas of Cusa: A Guide to a Renaissance Man, Mahwah, NJ, Paulist Press, 2004, pp. 280-284; Euler, «A Critical Survey of Cusanus' Writings on Islam», in Levy, George-Tvrtković and Duclow (eds.) Nicholas of Cusa and Islam, op. cit., pp. 26-27.

${ }^{35}$ Ibidem, p. 29. 
The Cribratio was dedicated by Cusanus to Pope Pius II when he was engaged in desperate efforts to wage his crusade against the Turks. A paragraph in Cusanus' preface of the Cribratio is telling. It praises Pius II for his stance against Islam, comparing him to «threefold holy» Pope Leo I «who with angelic genius and eloquence condemned the Nestorian heresy» of the $5^{\text {th }}$ Century Patriarch of Constantinople: "you show through the same spirit, and with equal genius and eloquence, that the Muhammadan sect (which has arisen from this heresy), is in error and is to be repudiated». ${ }^{36}$

Euler claims, based on this paragraph, that the Cribratio was intended by Cusanus to serve Pius II «as a collection of material for his letter to Sultan Mehmed II, the conqueror» ${ }^{37}$ In 1461, Pius II wrote a letter, which was never sent, to the Sultan Mehmed II. It suggested the Sultan convert to Christianity, the desirable outcome of which would result in his recognition by both Christians and Muslims as emperor of the East. ${ }^{38}$ Euler could be correct in

${ }^{36}$ Hopkins, p. 965; Moudarres, A., «Crusade and Conversion: Islam as Schism in Pius II and Nicholas of Cusa», MLN 128 (2013): 45; Cribratio Alkorani, p. 3, 1-10: «Sume, sanctissime papa, libellum hunc per humilem servulum tuum fidei zelo collectum, ut, dum more ter sancti Leonis papae praedecessoris tui Nestorianam haeresim apostolico spiritu, angelico ingenio divinoqu eloquio damnantis tu Mahumetanam sectam de illa exortam eodem spriritu, pari ingenio facundiauqe aequali erroneam eliminandamque ostendes, cito quaedam rudimenta scitu necessaria ad manum habeas».

${ }^{37}$ Euler, «An Italian Painting from the Late Fifteenth Century», op. cit., pp. 127-142 at p. 131.

${ }^{38}$ Aeneas Silvius Piccolomini (Pope Pius II), Epistola ad Mahomatem II (Epistle to Mohammed II), ed. and trans. A. Baca, New York, Peter Lang, 1990, pp. 17-18 [121-122: Opera, pp. 872-904 at p. 874): «Si vis inter Christianos tuum imperium propagare et nomen tuum quam gloriosum efficere, non auro, non armis, non excercitibus, non classibus opus est. Parva res omnium qui hodie vivunt maximum et potentissimum et clarissimum te reddere potest [...] id est aquae pauxillum, quo baptizeris et ad Christianorum sacra te conferas et credas Evangelio. Haec si feceris, non erit in orbe princeps qui te Gloria superset aut aequare potential valeat. Nos te Graecorum et Orientis imperatorem appellabimus et quod modo vi occupas et cum iniuria tenes possidebis iure». - «If you want to extend your power over Christians and render your name as glorious as possible, you do not need gold, weapons, armies, or fleet. A little thing can make you the greatest, most powerful and illustrious man of all who live today [...] it is a little bit of water by which you may be baptized and brought to Christian rites and to the belief in the Gospel. If you receive this, there will not be any leader in the world who can surpass you in glory or equal you in power. We will call you ruler over the Greeks and the East; what you now hold by force and injustice, you will rightfully possess». Arguing for the Pope's sincere intention to make the Sultan convert to Christianity: Babinger, F., Mehmed the Conqueror and His Time, Princeton, Princeton University Press, 1978, pp. 198-199; Hankins, J., «Renaissance Crusaders: Humanist Crusade Literature in 
arguing that Cusanus' Cribratio was to serve Pius II as a collection of material for this letter. However it seems doubtful that Cusanus' harsh anti-Islamic polemic, and in particular his definition of Islam as the religion of the sword, ${ }^{39}$ would persuade Mehmed the conqueror to convert.

Meanwhile, Hollman's treatment of De pace fidei and Cribratio Alkorani as a dialectical synthesis (coincidentia oppositorum) enabling «even the complicated connection of crusade and dialogue» seems like an attempt to square the circle. Hollman himself, while referring to Cusanus' notes on a copy of Robert of Ketton's translation of the Qur'an, half-heartedly admits that these "pastiche of references to peace fails to cover some of Cusanus's more polemical points on Islam in the Cribratio Alkorani, it nonetheless behoves careful readers to place condemnations of Islam in the context of the belligerent times [...]" 40 Hollman thus skirts over the problematic issue of Cusanus' polemical rhetoric.

\section{Religion of the Sword}

Cusanus stressed Muhammad's ignorance and claimed «that ignorance was the cause of [Muhammad's] error and malevolence», as well as sheer personal ambition, «For whereas Christ sought not his own glory but the glory of God-the-Father and the salvation of men, Muhammad sought not the glory of God and the salvation of men but rather his own glory». ${ }^{41}$ Unequivocally Cusanus states: "The Qur' an is devoid of faith where it contradicts the Sacred Scriptures [...] The Gospel is to be preferred to the Qur' an [...] Arabs must confess the Trinity [...] Muhammad did not know what ought to be done and what ought to be believed; and he left behind nothing firm [...]».42

the Age of Mehmed II», Symposium on Byzantium and the Italians, 13th-15th Centuries, Dumbarton Oaks Papers, 49 (2014), pp. 129-130. Ascribing other intentions to the pope: Bisaha, N., «Pius II's Letter to Sultan Mehmed II: A Reexamination», Crusades, 1 (2002), pp. 183-200; Bisaha, Creating East and West, pp. 86-87, 147-152.

${ }^{39}$ Euler, «An Italian Painting from the Late Fifteenth Century», op. cit., pp. 127-142 at p. 131.

${ }^{40}$ Hollman, Religious Concordance, pp. 179-180, 190 (the citations are on pp. 179, 190 respectively). Just one such polemical issue is cited (p. 190, n. 82), but not discussed.

${ }^{41}$ Hopkins, pp. 968-969; Cribratio Alkorani, prologus, pp. 11-12, 7: «Tenendum credimus ignorantiam erroris et malivolentiae causam esse». Dumbarton Oaks Papers, vol. 49 (2014): «[...] Christo non suam gloriam sed dei patris et hominum salutem, Mahumeto vero non dei gloriam et hominum salutem sed gloriam propriam quaerente».

${ }^{42}$ Hopkins, pp. 971-973; Cribratio Alkorani, alius prologus, pp. 18-19, 5: «IV. Quod Alkoran fide careat, ubi sacris scripturis contradicit. V. Quod evangelium sit Alkorano 
This essentially relates to those sections of the Qur'an which do not match or contradict Christian truths which Cusanus was eager to illuminate. Cusanus was averse to the idea of carnal pleasures in paradise, and he blamed Mohammed for introducing them into the Qur'an, directly accusing the prophet, «For no one speaks so vilely of such vile things unless he is full of all such vileness; for out of the abundance of the heart the mouth speaks». ${ }^{43}$ Most discreditable, in Cusanus view was that Islam was a «religion of the sword» and Cusanus explicitly persisted with this notion and saw Mohammed as responsible for this. His chapter-titles include one with the statement «[...] and that the sword is teacher». ${ }^{44}$ Thus, Muslims enforced their religion on Christians by the threat of the sword: «And countless apostate Christians and Arab Christians and Christians who being of the same law as the Arabs pretend to be of the Arab sect because of fear of the sword».$^{45}$ Cusanus went as far as proclaiming "Therefore, the sword is the final decisive proof of whatever is read in the Qur' an [...] [Muhammad] replied: «We have destroyed, says God, cities before the eyes of those who have not believed. And neither would you believe miracles, except by the sword [...]". ${ }^{46}$ As Cusanus saw it, Islam's ultimate goal was domination.

But you have seemed to me, Oh Muhammad, to have sought-under the pretext of religion-the power of dominating. For you reduce all [matters] to the sword; and even by the sword you strive to obtain tribute... Does anyone fail to understand that the goal of your religion-that your zeal and the rite [prescribed] by your law-tends only toward your dominating? ${ }^{47}$

praeferendum [...] XI. Necesse est Arabes fateri trinitatem [...] II. Quod Mahumetus ignoravit, quid agendum et sentiendum et nihil firmi reliquit».

${ }^{43}$ Hopkins, p. 1046; Cribratio Alkorani, II, p. 126, 6-8: «Nam tam turpia ita turpiter nemo loquitur nisi plenus omni tali turpitudine, ex abundantia enim cordis os loquitur».

${ }^{44}$ Hopkins, p. 973; Cribratio Alkorani, alius prologus, p. 19, 6: «[...] et quod gladius est magister».

${ }^{45}$ Hopkins, p. 979; Cribratio Alkorani, III, p. 29, 15-17: «Multi etiam Christiani sub principibus sectae Arabum Christo devotius serviunt et infiniti Christiani renegati et Arabes et eiusdem legis cum ipsis timore gladii [...]».

${ }^{46}$ Hopkins, p. 1061; Cribratio Alkorani, p. 137, 1-2: «Est igitur ultima resolutio probationis omnium, quae in Alkoran leguntur, gladius [...] Respondit: Destruximus - inquit deus - civitates ante eos, qui non crediderunt; nec etiam vos miraculis crederetis nisi per gladium etc».

${ }_{47}$ Hopkins, p. 1068; Cribratio Alkorani, VIII, p. 148, 1-9: «Sed visus es mihi, o Mahumete, praetextu religionis dominandi potentatum quaesivisse; omnia enim in gladium resolvis et gladio saltem ad tributum pervenire contendis. Persuasisti quemlibet in sua lege salvari posse ac quod deus fidelium constantiam diligat, variantes vero nequaquam. Deinde accipis gladium quasi illos velis ad varietatem compellere, quos 
Thus, Cusanus presented Islam in his Cribratio as a violent sect, a religion whose existence is no more than a pretext to exercise of the sword. Cusanus' extremely intolerant definition of Islam as «religion of the sword», clearly indicates a change of mind experienced by Cusanus, one that presumably reflects his growing fear of the Turkish menace, and the fear that Islam will take over.

How to reconcile this fearful view of Islam with Cusanus' more benign attitude elsewhere in his work? Jasper Hopkins explains that by pia interpretatio or benevolent interpretation, Cusanus sought to render the Qur'an consistent with the Gospel. "If viewed secundum piam interpretationem, the Qur' an can be seen to approve the Gospel». ${ }^{48}$ Thus "Some of the Qur' an's selfcontradictions, as well as some of its inconsistencies with both the Gospel and the Old Testament, are only apparent. They can be explained away by pia interpretatio». ${ }^{49}$ If positive references to Christian basics are to be found in the Qur'an, then it cannot be completely bad, and there must be a way of scrutinizing it adequately, to the advantage of Christianity. But it seems naive to regard this as a sign of moderation, or religious toleration on Cusanus' part. Pia interpretatio was an instrumental way of reading of the Qur'an and subjectively interpreting it with the aim of ultimately demonstrating the overall superiority of Christianity in general, and over Islam in particular. But as Hopkins points out, Cusanus does this in quite a «complex» way: presenting the Qur'an and Mohamad's faults and discrepancies in a harsh manner; without completely ruling out the Qur'an. After all, if traits of the true faith, i.e. Christianity, can be traced in the Qur'an, why reject it all together $?^{50} \mathrm{I}$ would argue that it is not just complex but highly sophisticated as well, much more than the total or blunt rejection of Islam of most Christian polemicists treating Islam before Cusanus. Yet, Cusanus' methodology and attitude with regard to the Qur'an should not be misinterpreted as moderate or tolerant.

Cusanus' Cribratio presents a completely different line of thought from that demonstrated in his De pace fidei. While, with its impressive utopian

animasti constantes manere, sed das optionem ipsis, ut vel varient vel tributum solvant. Quis non intelligit finem tuae religionis zelum et ritum tuae legis tantum ad hoc tendere, ut domineris» See Aikin and Aleksander, «Nicholas of Cusa's De pace fidei and the Meta-Exclusivism of Religious Pluralism», p. 223.

${ }^{48}$ Hopkins, «Introduction», op. cit., 24. See also Hopkins, J., «The Role of Pia Interpretatio in Nicholas of Cusa's Hermeneutical Approach to the Koran», in G. Piaia (ed.) Concordia Discors: Studi su Niccolò Cusano e l'umanesimo europeo offerti a Giovanni Santinello, Padova, Antenore, 1993, pp. 251-273.

${ }^{49}$ Hopkins, «Introduction», p. 24.

${ }^{50}$ Ibidem. 
scheme, De pace fidei, may certainly be described as a form of dialogue with Islam, the Cribratio «does not offer a satisfactory solution for dialogue with Islam in religious and political terms». ${ }^{51}$ Thus, Nancy Bisaha's emphasis on an ideological gap supposedly existing between the Pope and his Cardinal, ${ }^{52}$ should be modified if not considerably revised. A gap between Piccolomini's crusading tendency and Cusanus' De pace fidei irenic attitude did conspicuously exist. However, the ideological gap between the two diminishes or even wholly disappears once a comparison is made between Piccolomini's crusading inclinations and Cusanus' Cribratio Alkorani.

\section{Cusanus' Swerve}

Cusanus' stance regarding Pius II's planed crusade is significant. The Cardinal was supportive and involved in the efforts the Pope invested in setting the crusade in motion. ${ }^{53}$ Although nominated papal legate in Rome, Cusanus was in Mantua during the congress convened by Pius II (1459), or at least at a certain stage of that congress. According to a description by the Pope, Cusanus took part in welcoming Albert, margrave of Brandenburg, a glorified combatant and general (the «German Achilles»), who was about to join Pius II's military planned expedition. Albert's arrival to Mantua was an important step towards the fulfilment of Pius II's crusading plan, which Cusanus supported in practice and, so it seems, in spirit too. Cusanus

${ }^{51}$ Euler, «A Critical Survey of Cusanus' Writings on Islam», op. cit., 29.

${ }^{52}$ Bisaha, Creating East and West, pp. 150-151.

${ }^{53}$ See Housley, N., «Aeneas Silvius Piccolomini, Nicholas of Cusa, and the Crusade: Conciliar, Imperial, and Papal Authority», Church History, 86 (2017), pp. 657-660, who attributes to Cusanus a crusading desire before and after 1453 (pp. 664-665). Crusades were largely financed by papal indulgences. Izbicki, T.M., «The Legate Grants Indulgences: Cusanus in Germany in 1450-1453», in Izbicki, T.M., J. Aleksander and D.F. Duclow (eds.) Nicholas of Cusa and Times of Transition. Essays in Honor of Gerald Christianson, Leiden, Brill, 2019, pp. 81-95, studied Cusanus' active role in the distribution of papal indulgences in Germany during the early 1450', based on Acta Cusana (Edited at present by J. Helmrath and T. Woelki, formerly by E. Meuthen and H. Hallauer). Izbicki concludes (p. 95): «There was no evidence that Cusanus ever questioned the actual value of indulgences. Instead, his proclamation of spiritual favors contributed to negative comment on these concessions and their financial aspects. In the long run, the German sense of grievance over indulgences as sources of papal revenue, and the poor reputation of the Roman curia north of the Alps provided fertile ground for Martin Luther at the outbreak of the Reformation». So far we have no evidence pointing to the involvement of Cusanus in the distribution of indulgences for financing Pius II's crusade (bearing in mind that Acta Cusana has not yet reached documentation of the years 1458 et seqq). 
demonstrated this with a gesture. When Albert came to Mantua «the cardinal of San Pietro left the ranks and went out to meet him», while the Pope praised Albert «for his prompt and generous promises of support against the Turks» and endowed him with money and expensive gifts. ${ }^{54}$

Cusanus was about to join Pius II in Ancona when he died in Todi on August 11, 1464. The Pope died in Ancona three days later while vainly awaiting the launch of his crusade. Morimichi Watanabe wonders what Cusanus would have done had he arrived in Ancona. "Could he willingly support the crusade, though he had always believed in peace? If so, how would he have convinced himself to take such a position? Many questions remain unanswered; in history, ironic turns of events often occur». ${ }^{55}$ Yet Watanabe himself came up with some plausible explanations as to why Cusanus changed his mind. ${ }^{56}$ Firstly he suggests that Cusanus may have acquired a deeper understanding of Islam and the Qur'an and where it diverged from Christian doctrine, in particular in denying Christ as Son of God, the crucifixion and in the doctrine of the Trinity. Secondly Cusanus' move to Rome and acceptance of an official position as representative of Pope Pius II may have obliged him to adopt a more orthodox line, defending Christendom and attacking Islam. Thirdly, he developed a close personal friendship with Pope Pius II, and his desire to support him in his crusade against the Turks as declared at the Congress of Mantua may have influenced his attitude to Islam. And finally Watanabe points out that Cusanus was working from a translation of the Qur'an completed by Robert of Ketton in 1143, which contained several errors, and thus Cusanus could have misunderstood parts of the text..$^{77}$

These distinctive explanations are significant, yet they do not enable us to reconstruct the process through which Cusanus' mind went. In contrast to Watanabe's proposed explanations, certain researchers emphasize the crusade-oriented connection, which existed between the Pope and the cardinal, concluding that «The two old warriors [...] ended their lives away from Rome pursuing another ideal, a crusade in defence of Christendom». ${ }^{58}$

${ }^{54}$ Comment. III, 45, 3: «Huic Mantuam venienti cardinalis Sancti Petri extra ordinem occurit [...] laudavitque magnificis verbis, qui sua opera contra Turchos alacri et magno animo promisisset». The gifts are mentioned here too.

${ }^{55}$ Watanabe, «Cusanus, Islam, and Religious Tolerance», op. cit., p. 16.

${ }^{56}$ See n. 54.

${ }^{57}$ Watanabe, «Cusanus, Islam, and Religious Tolerance», op. cit., pp. 13-14.

${ }^{58}$ Izbicki, T.M., Christianson, G., and Krey, Ph., (ed. and trans.) Reject Aeneas, Accept Pius. Selected Letters of Aeneas Sylvius Piccolomini (Pope Pius II), Washington, DC, Catholic University of America Press, 2006, p. 53. 
For historians such as Hankins and Bisaha, who do not treat De pace fidei as a utopian vision, but as a sophisticated strategy intended to demonstrate the superiority of Christianity, Cusanus did not really change his mind. Hankins explained that «Cusanus developed a highly original ecumenical strategy that involved showing Jews, Muslim, Hindus, and others that their religions [...] contained all the essential truths of Christianity [...] This strategy he set out in his De pace fidei [...]»..$^{59}$ Nevertheless, De pace fidei has a significant utopian notion which must not be overlooked or belittled, and the gap between its universal and pacifistic essentials and the conspicuous polemical elements of the Cribratio are not easily reconciled, if at all.

During the eight years that passed between the appearance of De pace fidei (1453) and the publication of Cribratio Alkorani, Cusanus did change his mind concerning Islam. How early might that have happened? Cusanus' references to the Turks and Islam, in a sermon which he composed in praise of the victory over the Turks near Belgrade in the summer 1456, are telling. First he explicitly links Christ's suffering to then enemies of Christendom, the Turks: "Christ suffered many persecutions in his mystic body, and much by that most savage Mehmed the Turk, the despiser of the cross of our Christ». Then he characterises apostate Christians who have converted to Islam as «spiritless» and ruled only by the senses. He then describes Mohammed as a "pseudoprophet» and explains the positive references to the Gospels in the Qur'an as the beguiling deception of Satan, emphasizing the doctrinal divergence of denying the crucifixion.

Thus, he praised Christ and the Gospel, but posited false insights while promising paradisiac lust of flesh and body. And since the cross of Christ is the ultimate spiritual testimony of conceiving the Gospel [...] therefore it seems that Satan induced Mohamed's doctrine to people so that the head of evil, the son of perdition, will spring out of it and constitute himself as the enemy of the cross of Christ.

Finally, he explicitly links this deception and battle between good and evil to contemporary historical events, associating victory in this battle with the prospective re-conquest of Constantinople:

But God permitted that the persecutor of the cross reigns until Constantinople, the new city of Rome with its plenty of sacred temples, could be regained. As for those inhabitants who schismatically deserted the unity of Catholic faith and the procession of the Holy Spirit they did not keep their secret promise of fidelity finally made at the synod of Florence to lend help

${ }^{59}$ Hankins, «Renaissance Crusaders», op. cit., p. 128; Bisaha, Creating East and West, op. cit., pp. 144-147. 
for the purpose of fighting the Turks. Their choice to follow temporal convenience is a deceitful act. ${ }^{60}$

In this text Cusanus wishes for the regaining of Constantinople from the Ottomans by war. This and the harsh language in referring to Islam and Mohammed make it clear that Cusanus' approach to Islam resembled no more De pace fidei, but was already very much in the denigrating terms and spirit of the Cribratio Alkorani. Thus, the sermon might be the key to understanding the essential difference between De pace fidei and Cribratio Alkorani. In 1453, after the fall of Constantinople, Cusanus inclined toward appeasement and toleration. Three years later Cusanus' mind concerning Islam and the Turks seems to be different.

The sermon provides key evidence that the geo-political situation of the time was of great importance. The fear that Mehmet II would take over Hungary, and perhaps proceed as far as Vienna (as Suleiman I did in 1529) was not baseless. What would have happened if Mehmet II was not stopped at Belgrade? Speculations aside, the Turkish menace was tangible and fearinspiring. Although defeated in Belgrade (July 22, 1456), Mehmet II took over

${ }^{60}$ Sermo CCXL Laudans invocabo Dominum at the Biblioteca Apostolica Vaticana, MS Vat. lat. 1245 (the translation to English is mine): «Passus est Christus multas persecutiones in corpore suo mystico, maxime autem per saevissimum istud, Mahometh Turkum contemptorem crucis Christi nostri. Multi quidem Saraceni a fide Christi abierunt, quia animalis homo quae sunt spiritus Dei percipere nequit I Cor 2,14. [...] Et quia homo animalis non concipit vitam laetam nisi animaliter et sensibiliter, diabolus subtiliter inficere volens evangelium introduxit pseudoprophetam Mahometh quasi sciolum evangelii et scripturae, ut daret intellectum animalem, qui gratus est homini animali. Sic laudavit Christum et evangelium, sed apposuit falsum intellectum promittens paradisum voluptatis secundum carnem et delicias corporales. Et quoniam crux Christi est ultimum testimonium spiritualis intelligentiae evangelii [...] ideo doctrinam Mahometh diabolus videtur hominibus persuasisse, ut ex ipsa veniret caput malitiae filius perditionis, qui se inimicum crucis Christi constitueret. Permisit autem Deus regnare persecutorem crucis quousque illam magnam novam Romam civitatem Constantinopolitanam plenam templis sanctissimis occuparet. Nam illi inhabitatores ab unitate fidei catholicae quoad processionnem Spiritus Sancti scismatice recesserunt et demum fidem subdole promissam in synodo Florentina ad finem habendi contra Turkum adiutorium non servaverunt. Non enim nisi delusorie accesserunt ad finem, ut temporale commodum assequerentur». See also Hankins, «Renaissance Crusaders», op. cit., p. 128 (n. 49); O'Malley, J.W., Praise and Blame in Renaissance Rome. Rhetoric, Doctrine, and Reform in the Sacred Orators of the Papal Court, c. 14501521, Durham, NC, Duke University Press, 1979, p. 234 nn. 156-157; Euler, «A Critical Survey of Cusanus' Writings on Islam», op. cit., p. 27. 
Serbian territories and means of self-governing during $1454-1456 .{ }^{61}$ The expansion of Ottoman power over the Balkans, posing a threat to Hungary and Austria, might have caused Cusanus to reject his tolerant De pace fidei attitude and adopt a stronger tone.

But there is also evidence that the shift in Cusanus' thinking began slightly earlier. Euler noticed that in his letter to John of Segovia (December 29, 1454), Cusanus adds a remark which testifies to a certain change of his mind. Though the letter is predominantly tolerant and appeasing, De pace fidei style, the remark reads: "It seems as if we are obliged to keep trying to interpret that book [the Qur'an], so important to them, as being commissioned for our sake. For we find things in it that are useful to us, and we will interpret all the others which are contrary according through the first ones». ${ }^{62}$

Euler claims that these words are Cusanus' first expression since De pace fidei, of his new attitude toward the Qur'an - or parts of it, at least - as contradictory to Christianity. Moreover, these words also demonstrate Cusanus' insistence on taking advantage of other parts of the Qur'an to be used in favour of Christianity - by way of faithful interpretation (pia interpretatio). According to Euler, Cusanus' change of mind took place during the fifteen months that lay between the composition of De pace fidei and Cusanus' letter to John of Segovia. It seems that the transition was a gradual process over time which started, as Euler points out, sometime after Cusanus wrote his De pace fidei and before he composed his letter to John of Segovia. The process was completed by 1456, as the sermon shows. By that point, Cusanus' outlook had completed a swerve: the De pace fidei spirit had faded away and given way to a Cribratio Alkorani approach.

${ }^{61}$ For restoration of events and dates of Mehmed's military steps after he conquered Constantinople, see: Inalcik, H., «Mehmed the Conqueror (1432-1481) and His Time», Speculum, 35 (1960), pp. 408-427; Inalcik, Essays in Ottoman History. Istanbul, EREN, 1998, pp. 87-110.

${ }^{62}$ Epistula ad Ioannem de Segobia in Nicolai de Cusa De pace fidei. Cum epistula ad Ioannem de Segobia, ed. Raymundus Klibanky and Hildebrandus Bascour, Hamburg, Felix Meiner, 1959, Nicolai de Cusa opera omnia, vol. 7, p. 99, 22-25: «Unde videtur quod semper ad hoc conandum sit quod liber iste, qui apud eos est in auctoritate, pro nobis allegetur. Nam reperimus in eo talia quae serviunt nobis; et alia quae contrariantur, glosabimus per illa». Euler, "A Critical Survey of Cusanus' Writings on Islam», in Levy, George-Tvrtković and Duclow (eds.) Nicholas of Cusa and Islam, op. cit., pp. 26-27. 


\section{Semichristiani}

Erasmus uses the term Semichristiani twice in his essay War is sweet to those who never experienced it (Dulce bellum inexpertis, 1515): «Indeed, those who are called Turks by us are largely half-Christians [...]», and «We are preparing to quench the whole of Asia and Africa with the sword, though most of the population there are either Christian or half-Christian». ${ }^{63}$ And again, in his De bello Turcico: «They are first of all human beings, then half-Christians». ${ }^{64}$ In the same work, Erasmus states: «The blessed Paul pointed out to us the good hope that the day will come when the stubborn Jewish nation will convert to Christianity and recognize the one and only Jesus Christ as our shepherd. Besides, there is hope that the Turks and other barbaric nations, which, as I hear, are not pagans but half-Christians in their faith». ${ }^{65}$

In the epilogue of her Creating East and West, Nancy Bisaha argues that Erasmus' definition of Muslims as «half-Christian» echoes Nicholas of Cusa's optimistic view of the Turks» ${ }^{66}$ However, Cusanus never used the term semichristiani in his writings, either in his De pace fidei or in his Cribratio Alkorani or any other writing. As for Cusanus' optimism, this is certainly valid as far De pace fidei is concerned, but not as regards Cusanus' later Cribratio, as already demonstrated. ${ }^{67}$

Undoubtedly, the term semichristiani expressed the recognition by Christians that Islam acknowledged the revelations of God at the basis of Judaism and Christianity, whether to Abraham, Moses, or to Jesus. ${ }^{68}$ Erasmus saw little to be impressed by in this. «They acknowledge Christ as just one of

${ }^{63}$ CWE 35, 433; ASD II-7, 39-40 (Adagia IV, i1; no.3001): «Atqui quos nos vocamus Turcas, magna parte semichristiani sunt [...] Nos totam Asiam et Africam ferro paramus extinguere, quum plurimi sint illic vel Christiani vel semichristiani».

${ }^{64}$ CWE 64, 233; ASD V-3, 52: «[...] illos primum esse homines, deinde semichristianos».

${ }^{65}$ CWE 64, 243; ASD V-3, 62: «Nam beatus Paulus nobis spem bonam ostendit, fore, ut aliquando Judaeorum pertinacissima natio ad idem ovile congregetur, ac nobiscum agnoscat unum Pastorem Jesum. Quanto magis id sperandum de Turcis reliquisque barbaris nationibus, quarum, ut audio, nulla colit Idola, sed dimidiatum habent Christianisimum».

${ }^{66}$ Bisaha, Creating East and West, op. cit., pp. 174-175. On Erasmus' Muslims as «halfChristians», see: Hampton, T., «Turkish Dogs: Rabelais, Erasmus, and the Rhetoric of Alterity», Representations, 41 (1993), pp. 62-63.

${ }^{67}$ See pp. 6-14.

${ }^{68}$ Williams, G.H., «Erasmus and the Reformers on Non-Christian Religions and Salus Extra Ecclesiam», in T.K. Rabb and J.E. Seigel (eds.), Action and Conviction in Early Modern Europe. Essays in Memory of H. Harbison, Princeton, Princeton University Press, 1969, p. 332. 
their prophets. The Jews do the same», ${ }^{69}$ and he goes on to denounce the Turks and the Jews for their false faith. "Their sect», Erasmus writes of Islam, «is a mixture of Judaism, Christianity, paganism, and the Arian Heresy». ${ }^{70}$ In his analysis of Islamic essence, Erasmus uses the term «half-Christian» not with Cusanus' De pace fidei optimism, but a rather typical medieval perspective which matches closely with Piccolomini's description of «[...] Muhammad, an Arab steeped in gentile error and Jewish perfidy, who received instruction in the Nestorian and Arian heresies». ${ }^{71}$

Erasmus used the term semichristiani within the framework of a Christian moral rhetoric emphasizing a need for a correction of Christian life (correctio vitae). ${ }^{72}$ Christians, not Turks, were Erasmus' concern. Erasmus deliberately uses rhetorical exaggeration in describing the Turkish evil in his writing with the intention of stressing that the Turks, although corrupt and cruel, were better than the Christians. In this way, Erasmus added greater urgency to his call of alarm for a Christian correction of life.

Additionally, Erasmus' definition of the Turks as «half-Christian» can be seen as an expression of wishful thinking, a will to convert them to Christianity. ${ }^{73}$ Erasmus had a conception of the Turks becoming Christians, who would follow the supposedly moral Evangelical examples set by emissaries who would be sent to the Ottoman Empire and this informs his use of the term semichristiani. It meant that cruel, blood-thirsty and immoral as they were (in Erasmus' view), the Turks were capable of understanding and being influenced by the moral examples such emissaries would be expected to set forward.

As already pointed out, Erasmus demonstrated a hostile attitude toward Islam, derogatory towards the Turks. His De bello Turcico consists of harsh and abusive references not just concerning the Turks but also regarding the essence

${ }^{69}$ CWE 64, p. 259; ASD V-3, p. 76: «Agnoscunt Christum ut unum quempiam ex prophetis».

${ }^{70}$ CWE 64, pp. 258-259; ASD V-3, p. 76: «Sectam habent ex Iudaismo, Christianismo, Paganismo et Arianorum haeresis commixtam».

${ }^{71}$ Comment. II, I, 5, (p. 211): «[...] Mahumetem [...] qui fuit Arabs gentili errore et Iudaica imbutus perfidia audivitque Christianos, qui Nestoriana et Ariana labe infecti errant». See: Moudarres, «Crusade and Conversion», op. cit., pp. 43.

${ }^{72}$ On the moral meaning of the war against the Turks: Weiller, A.G., «The Turkish Argument and Christian Piety in Desiderius Erasmus' Consultatio de Bello Turcis inferendo (1530)», in W.J. Sperna and W.T.M. Frijhoff (eds.), Erasmus of Rotterdam the Man a and the Scholar, Leiden, Brill, 1988, pp. 30-39.

${ }^{73}$ Erasmus' suggestions for converting the Turks: CWE 64, p. 265, ASD V-3 81; CWE 66, pp. 10-11; Ep. 858, 103-107. 
of Islam and Mohammed. Erasmus used his characterization of genus Turcarum to embody all that was wrong with the Christian world: «If we really want to heave the Turks from our necks, we must first expel from our hearts a more loathsome race of Turks, avarice, ambition, the craving for power, self-satisfaction, impiety, and extravagance, the love of pleasure, deceitfulness, anger, hatred, and envy.) ${ }^{74}$ In Erasmus' mind, corruption and immorality was the Turkish essence and for him the Turkish race represented a form of inhumanity, expressed by the term Immanitas Turcarum. As Hankins interprets, «Immanis was the very word that the humanists used over and over again to describe the Turk. It is the lexical opposite of humanitas, the word that expresses the Renaissance ideal of culture. In humanist histories and orations, immane genus replaced infideles as the preferred epithet for the Turks». ${ }^{75}$ This overshadows any moderation or toleration attributed to Erasmus due to his definition of Muslims as semichristiani. Consequently, it should be recognized that Erasmus' anti-Turkish/Muslim attitude was far from the moderate and tolerant and attitude toward Islam and the Turks expressed in Cusanus' De pace fidei.

Morover, Erasmus' vision of inter-religious relations was fundamentally different from Cusanus' universal «one religion in different rituals» expressed in his earlier work. However, similarities of polemical elements concerning Islam can be found between Cusanus' much less moderate or tolerant Cribratio and Erasmus' De bello Turcico. Erasmus' attitude towards Turks and Islam is similar to Cusanus' attitude expressed in Cribratio, when he writes of convincing the Muslims to convert by explaining and proving to them that Christianity is superior to Islam. Erasmus' future vision is telling. "The name of Christ [...] will be recognized, celebrated and worshipped throughout the whole world, as the psalm says: that all nations, in different tongues but with a single voice, in one single temple, one united church, shall sing glory to their redeemer». ${ }^{76}$

Erasmus envisaged the existence of one religion, which would be embodied by a uniform monolithic church and would not recognize a variety of rituals. But this was also Nicholas of Cusa's wish - Cribratio's aim was, in the final analysis, to

${ }^{74}$ CWE 64, p. 242; ASD V-3, p. 62: «Si nobis succedere cupimus, ut Turcas a nostris cervicibus depellamus, prius teterrimum Turcarum genus ex animis nostris exigamus, avaritiam, ambitionem, dominandi libidinem, nostri fiducia, impietatem luxum, voluptatum amorem, fraudulentiam, iram, odium, invidiam».

${ }^{75}$ Hankins, «Renaissance Crusaders», op. cit., 122.

${ }^{76}$ CWE 64, 243; ASD V-3 62: «[...] Christi nomen [...] per universum terrarum orbem agnosci, celebrari, adoriri, juxta Psalmum. Universas nationes variis linguis, sed concordibus in eodem templo, hoc est in unitate Ecclesiae Redemtori suo canere gloriam». 
argue for Christian superiority over Islam in order to make Muslims convert to Christianity, just as Pius II suggested to the Sultan in his famous unsent letter.

\section{Conclusions}

Any observation of an ideological linkage that might have existed between Cusanus' outlook and others, such as Pius II or Erasmus, must take into account the distinction which exists between Cusanus' early De pace fidei utopian-irenic vision and his later instrumental scrutiny of the Qur' an.

The passion for crusading and Cusanus' De pace fidei irenic attitude are completely incompatible, while religious warlike passion and Cusanus' Cribratio approach are quite consistent. In essence, the Cribratio should be interpreted as reflecting the later Cusanus' ideological affinity, if not identity with Pius II as far as the Turkish threat was concerned.

As for defining Erasmus' attitude toward the Turks as moderate or tolerant based on his characterization of Muslims/Turks as "half-Christian», echoing Cusanus' optimistic view of the Turks, this should be rejected in light of the following findings: Cusanus never used the term semichristiani in his writings. The term semichristiani sits in Erasmus' writings side by side with manifest contempt and degradation in relation to the Turks. Erasmus' rhetoric and hostile attitude toward the Turks/Islam are far from the moderation and toleration which Cusanus presents in his De pace fidei.

As far as Erasmus' concordia was concerned, namely his notion of an exclusively Christian peace which did not include Turks and Jews (unless they converted), Erasmus was consistent and unequivocal throughout his writings. ${ }^{77}$ In contrast, Cusanus' De pace fidei was not exclusivist but containing and tolerant. However, his Cribratio presents quite a different attitude toward Islam, much closer to Erasmus' De bello Turcico.

Nathan Ron

nron2@staff.haifa.ac.il

77 Turchetti, M., «Religious Concord and Political Tolerance in Sixteenth and Seventeenth Century France», Sixteenth Century Journal, 22 (1991), pp. 15-25. Turchetti observes that Sebastian Castellio's willingness to recognize other religions in Europe beside Catholic Christianity was in no way influenced by Erasmus who profoundly believed that Catholic Christianity was the one and only true religion. Admittedly, Erasmus never called for religious freedom or religious pluralism: Ron, «The Christian Peace of Erasmus», op. cit. 